\title{
Formation and global distribution of sea-surface microlayers
}

\author{
O. Wurl, E. Wurl, L. Miller, K. Johnson, and S. Vagle \\ Institute of Ocean Sciences, Fisheries and Oceans Canada, Sidney, British Columbia, V8L 4B2, Canada \\ Received: 12 June 2010 - Published in Biogeosciences Discuss.: 23 July 2010 \\ Revised: 28 December 2010 - Accepted: 4 January 2011 - Published: 18 January 2011
}

\begin{abstract}
Results from a study of surfactants in the seasurface microlayer (SML) in different regions of the ocean (subtropical, temperate, polar) suggest that this interfacial layer between the ocean and atmosphere covers the ocean's surface to a significant extent. New, experimentally-derived threshold values at which primary production acts as a significant source of natural surfactants to the microlayer are coupled with a wind speed threshold at which the SML is presumed to be disrupted, and the results suggest that surfactant enrichment in the SML is greater in oligotrophic regions of the ocean than in more productive waters. Furthermore, surfactant enrichments persisted at wind speeds of up to $10 \mathrm{~m} \mathrm{~s}^{-1}$, without any observed depletion above $5 \mathrm{~m} \mathrm{~s}^{-1}$. This suggests that the SML is stable enough to exist even at the global average wind speed of $6.6 \mathrm{~m} \mathrm{~s}^{-1}$. Using our observations of the surfactant enrichments at various trophic levels and wind states, global maps of primary production and wind speed allow us to extrapolate the ocean's SML coverage. The maps indicate that wide regions of the Pacific and Atlantic Oceans between $30^{\circ} \mathrm{N}$ and $30^{\circ} \mathrm{S}$ may be more significantly covered with SML than north of $30^{\circ} \mathrm{N}$ and south of $30^{\circ} \mathrm{S}$, where higher productivity (spring/summer blooms) and wind speeds exceeding $12 \mathrm{~m} \mathrm{~s}^{-1}$ may prevent extensive SML formation.
\end{abstract}

\section{Introduction}

The sea-surface microlayer (SML) represents the boundary interface between the atmosphere and ocean, covering about $70 \%$ of the Earth's surface. The SML can be summarized as being a micro-habitat with a total thickness between 1 and $1000 \mu \mathrm{m}$ (Liss and Duce, 1997). A SML of a thickness of

Correspondence to: O. Wurl

(owurl_nautilus@inbox.com)
$60 \mu \mathrm{m}$ could be meaningfully used for studying the physicochemical properties of the SML (Zhang et al., 2003) and up to $1000 \mu \mathrm{m}$ for biological properties, depending the organism or ecological features of interest. Despite the thinness of the SML, this interface may play a significant role in biogeochemical processes on a global scale, including air-sea gas and heat exchange (Liss and Duce, 1997), particle cycling (Wheeler, 1975; Wurl and Holmes, 2008), and microbial loops (Reinthaler et al., 2008).

The SML is known to concentrate, to varying degrees, many chemical compounds, in particular those that are surface-active (surfactants). The enrichment of naturally occurring organic compounds, such as carbohydrates, proteins, and lipids, modifies the chemical and physical properties of the sea surface. The primary sources of natural surfactants are phytoplankton exudates (Žutic et al., 1981), which are transported to the surface via rising bubbles and diffusion. Carbohydrates represent a high fraction of the exudates and are potentially surface-active (Plavšić and Ćosović, 2000). High molecular polysaccharides and complex $\beta$-glucans are major excretion productions of marine phytoplankton (Allan et al., 1972; Mykelstad, 1974) and frequently found in seawater during blooms (Sakugawa and Handa, 1985). The hydrophilic polysaccharides may conjugate to hydrophobic moieties, making them surface active, and become enriched in the SML by factors of up to 3 compared to subsurface waters (Williams et al., 1986; Wurl and Holmes, 2008; Wurl et al., 2009). At the ocean surface, the surfactants form thin films, which have been found to significantly dampen air-sea gas exchange (Broecker et al., 1978; Goldman et al., 1988; Frew et al., 2002). Thus, such surfactant films have the potential to cause significant biases in estimates of air-sea gas exchange rates of greenhouse gases $\left(\mathrm{CO}_{2}, \mathrm{CH}_{4}, \mathrm{~N}_{2} \mathrm{O}\right.$, DMS), thereby affecting our understanding of the Earth's radiation budget.

Published by Copernicus Publications on behalf of the European Geosciences Union. 
Asher (1997) and Tsai and Lui (2003) assessed the effect of the SML on global air-sea $\mathrm{CO}_{2}$ fluxes using global ocean primary productivity maps and suggested that the annual net flux is reduced by at least $20 \%$. However, the authors chose arbitrary threshold values (i.e., not derived from experimental data) of local primary production as an indicator for the presence of surfactant films. The threshold values of two different scenarios were 0.50 and $0.83 \mathrm{~g} \mathrm{C} \mathrm{m}^{-2} \mathrm{day}^{-1}$, and regions above those thresholds have been defined as being influenced by surface films (i.e., SML) (Tsai and Lui, 2003).

Liss (1975) recognized that rising air bubbles coated with surface-active organic matter are a major transport vector of these substances from the bulk water to the ocean surface. Bubbles bursting at the ocean's surface eject only a small fraction of the organic matter to the atmosphere as aerosols, and the remaining fraction is available for the formation of surfactant films (Liss, 1975).

Wurl et al. (2009) have observed enrichment of surfaceactive substances in the SML, relative to bulk water, of up to a factor of 2 at wind speeds exceeding the average global wind speed over the ocean of $6.6 \mathrm{~m} \mathrm{~s}^{-1}$ (Archer and Jacobson, 2005). Earlier reports in the literature (Sieburth et al., 1976; Williams et al., 1986; Reinthaler et al., 2008) have already indicated that surfactant enrichment in the SML can exist under typical open ocean conditions. Therefore, wind conditions need to be considered when assessing the distribution and formation of surface surfactant films.

This study presents a first estimate of the ocean's coverage with SML based on experimental data using primary productivity and wind speed as indicators for the presence of the SML. Threshold values of the indicators have been derived from statistical evaluation of the enrichment of surfactants and dissolved carbohydrates in the SML from observations made in tropical, temperate, and polar regions. The study was designed to answer the general question whether the SML needs to be considered in regard to air-sea gas exchange and biogeochemical cycles. However, this limited data set is not sufficient to definitively assess microlayer effects on a global scale.

\section{Methods}

\subsection{Study areas}

Samples have been collected at a coastal site in Saanich Inlet (British Columbia, Canada); during two cruises as part of the Radiance in a Dynamic Ocean (RadyO) project; during one cruise as part of the ArcticNet program; and two cruises (Line $\mathrm{P}$ and LaPerouse) as part of programs conducted in the Northeast Pacific by the Institute of Ocean Sciences, Fisheries and Oceans Canada. All sampling areas are summarized in Table 1 with further references to provide details of the sampling regions. The sampling areas represent three trophic states (oligo-, meso-, and eutrophic), as well as numerous climatic conditions (Fig. 1).

Regular sampling throughout the year (June 2008 to May 2009) has been conducted at the coastal site in Saanich Inlet, which is a steep-sided fjord-type inlet, consisting of a long $(28 \mathrm{~km})$ and deep $(200 \mathrm{~m})$ basin separated from a channel to the north by a shallow $(60 \mathrm{~m})$ sill. High primary productivity due to water stratification and resupply of nutrients through strong tidal currents has been observed in Saanich Inlet for many decades (Timothy and Soon, 2001).

\subsection{Sample collection}

We collected 337 paired SML and subsurface water $(1 \mathrm{~m}$ depth) samples, including 60 samples during slick conditions. Samples from the SML were collected using a glass plate sampler (Harvey and Burzell, 1972) from the bow of a small boat. The glass plate was immersed vertically and withdrawn gently at a speed of $5-6 \mathrm{~cm} \mathrm{~s}^{-1}$ (as consistently as conditions allowed) despite a higher withdrawal rate of $20 \mathrm{~cm} \mathrm{~s}^{-1}$ originally suggested by Harvey and Burzell (1972). The slower withdrawal rate collects the SML with a thickness of about $50 \mu \mathrm{m}$ (Carlson, 1982), which is consistent with experimentally determined SML thicknesses of $50 \pm 10 \mu \mathrm{m}$ using $\mathrm{pH}$ microelectrodes (Zhang et al., 2003). At higher wind speeds above $6 \mathrm{~m} \mathrm{~s}^{-1}$, i.e. in the presence of larger breaking waves, we dipped the glass plate between two breaking waves. Under such conditions, we had to collect the SML samples at a faster withdrawal rate (8$10 \mathrm{~cm} \mathrm{~s}^{-1}$ ), about half the rate originally suggested by Harvey and Burzell (1972) to ensure integrity of SML samples adhering to the glass plate, resulting in thicker samples $(\approx 80-120 \mu \mathrm{m})$. Glass plate dips affected by splashing water were rejected. Each adhering SML sample was scrapped off with a neoprene blade and collected in aged and acid-washed HDPE bottles free of leachable organic matter. Volumes of $50-150 \mathrm{~mL}$ were collected for each SML sample, requiring 30-90 dips.

During the ship-based cruises, we conducted the sampling at a distance of $500 \mathrm{~m}$ upwind from the mother ship to avoid potential contamination. A total of nine samples were collected under partly ice-covered conditions at sampling area AC 2 (Fig. 1) from an ice cage lowered by a crane from the bow of the ship. The ship was positioned so that the surface water flowed from open waters towards the sampling point to minimize the contamination risk. Subsurface samples from $1 \mathrm{~m}$ were collected with a 12-volt DC Teflon gear pump and polypropylene tubing. Separate subsurface samples from 1 and $8 \mathrm{~m}$ were filtered onto Whatman GF/F filters (47 mm diameter; 500-2000 mL) for chlorophyll- $a$ (Chl- $a$ ) analysis. All samples were stored cool during sampling operations. All sampling equipment was washed with $10 \% \mathrm{HCl}$ and rinsed with ultra-pure water prior to use.

In the land-based laboratory (for sampling in Saanich Inlet) or the ship's laboratory, sub-samples $(4 \mathrm{~mL})$ for total 
Table 1. Details of sampling events and local primary production (PP).

\begin{tabular}{|c|c|c|c|c|c|c|}
\hline \multirow[t]{2}{*}{ Sampling region } & \multirow[t]{2}{*}{ Cruise } & \multirow[t]{2}{*}{$\begin{array}{l}\text { Sampling } \\
\text { period }\end{array}$} & \multirow[t]{2}{*}{ \# samples ${ }^{\mathrm{a}}$} & & \multicolumn{2}{|c|}{ Mean $\pm \mathrm{sd}$ of PP in $\left[\mathrm{g} \mathrm{C} \mathrm{m}^{-2} \mathrm{day}^{-1}\right]^{\mathrm{b}}$} \\
\hline & & & & & this study & literature \\
\hline $\begin{array}{l}\text { Santa Barbara Channel, } \\
\text { California (CA) }\end{array}$ & $\mathrm{RaDyO}$ & $\begin{array}{l}9 \text { September } 2008 \\
-22 \text { September } 2008\end{array}$ & 26 & $\begin{array}{l}\text { Coastal } \\
\text { (offshore) }\end{array}$ & $1.07 \pm 0.12$ & $1.24^{\mathrm{d}}$ \\
\hline Vancouver Island (VI) & LaPerouse & $\begin{array}{l}27 \text { May } 2009 \\
-6 \text { June } 2009\end{array}$ & 12 & $\begin{array}{l}\text { Coastal (near- } \\
\text { and offshore) }\end{array}$ & $1.68 \pm 0.85$ & \\
\hline North Pacific (NP) & Line $\mathrm{P}$ & $\begin{array}{l}7 \text { June } 2009 \\
-20 \text { June } 2009\end{array}$ & 19 & open ocean & $0.49 \pm 0.25$ & $0.70 \pm 0.30^{\mathrm{e}}$ \\
\hline $\begin{array}{l}\text { North Pacific, tropical, } \\
\text { Hawaii (HI) }\end{array}$ & $\mathrm{RaDyO}$ & $\begin{array}{l}27 \text { August } 2009 \\
-13 \text { September } 2009\end{array}$ & 23 & $\begin{array}{l}\text { coastal (offshore) } \\
\text { open ocean }\end{array}$ & $\begin{array}{l}1.05 \pm 0.21 \\
0.55 \pm 0.11\end{array}$ & $0.47 \pm 0.13^{\mathrm{f}}$ \\
\hline
\end{tabular}

${ }^{\mathrm{a}}$ total number of samples (non-slick and slick); ${ }^{\mathrm{b}} \mathrm{sd}=$ standard deviation; ${ }^{\mathrm{c}}$ Timothy and Soon (2001); ${ }^{\mathrm{d}}$ Shipe and Brzezinski (2003), no sd reported, mean value for time period April to August; ${ }^{\mathrm{e}}$ Welschmeyer et al. (1993); ${ }^{\mathrm{f}}$ Karl et al. (1998); ${ }^{\mathrm{g}}$ Lavoie et al. (2009)

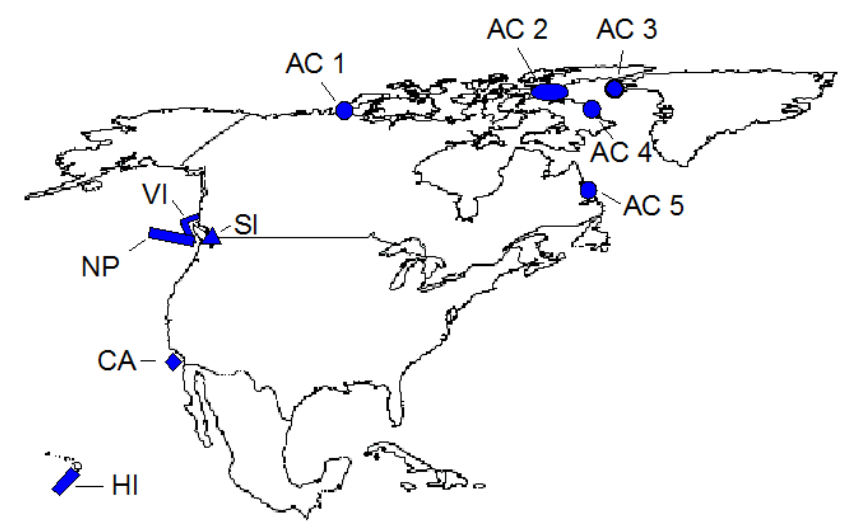

Fig. 1. Sampling stations. AC: Arctic; CA: California, Santa Barbara Channel; HI: Hawaii; NP: North Pacific; SI: Saanich Inlet; VI: Vancouver Island, West Coast.

dissolved carbohydrates (TDC) were filtered over $0.2 \mu \mathrm{m}$ polycarbonate filters pre-washed in $10 \% \mathrm{HCl}$. Filtrates were stored in pre-combusted $\left(450{ }^{\circ} \mathrm{C}\right.$ for $\left.5 \mathrm{~h}\right)$ screw-cap test tubes. Sub-samples for TDC and GF/F filters for Chl- $a$ analysis were stored at $-20^{\circ} \mathrm{C}$. Unfiltered sub-samples for surfactant analysis were analyzed on the day of collection, except for the cruises offshore California (Santa Barbara Channel, CA) and Hawaii (HI) (Table 1). On those cruises, unfiltered sub-samples were preserved with $1 \%$ formalin (final concentration) and stored at $4{ }^{\circ} \mathrm{C}$ for up to 6 weeks until analysis in the home laboratory. This preservation technique stabilizes unfiltered samples for surfactant analysis for a period of at least two months (Wurl et al., 2009).
At the time we collected each SML sample, we also measured instant wind speed and air temperature using a handheld weather station (Kestrel, Model 3000). Wind speeds prevailing prior to sampling events were recorded by weather stations deployed on a buoy at Saanich Inlet or on the ships.

\subsection{Chemical analyses}

We measured the concentration of surfactants, TDC, and chlorophyll at all stations. Surfactants were analyzed by phase-sensitive alternating current voltammetry with a hanging mercury drop electrode in unfiltered samples $(10 \mathrm{~mL}) \mathrm{ac}-$ cording to Ćosović and Vojvodić (1998). Surface-active substances were accumulated at the hanging mercury drop electrode at a potential of $-0.6 \mathrm{~V}$ (versus an $\mathrm{Ag} / \mathrm{AgCl}$ reference electrode) with stirring. Stirring time was in the range of 20 to $60 \mathrm{~s}$ depending on the concentration. The frequency of a.c. voltage was $170 \mathrm{~Hz}$ and the p-p amplitude was $10 \mathrm{mV}$. Scan rate was $20 \mathrm{mV} \mathrm{s}^{-1}$. The out-of-phase signal of the alternating current was measured. The total concentration of surfactants is expressed as the equivalent concentration of the nonionic surfactant Triton X-100 (Teq), which mimics effects similar to natural surfactants. To eliminate matrix effects, the concentrations were determined using the standard addition method (Sander and Henze, 1997). The reproducibility for triplicate samples was typically better than $10 \%$.

The concentrations of TDC were determined spectrophotometrically using 2,4,6-tripyridyl-s-triazine (TPTZ) as a complexing reagent (Myklestad et al., 1997). Prior to analysis, the samples $(4 \mathrm{~mL})$ were subjected to hydrolysis with $0.85 \mathrm{M} \mathrm{H}_{2} \mathrm{SO}_{4}$ (final concentration) at $100{ }^{\circ} \mathrm{C}$ for $24 \mathrm{~h}$ to convert polysaccharides to monosaccharides (Borch and 
Kirchman, 1997). The procedure typically has a precision better than $7 \%$.

For Chl- $a$ determination, $200-1000 \mathrm{~mL}$ of bulk water $(1 \mathrm{~m}$ and $8 \mathrm{~m}$ ) were filtered in duplicate, and the filters were extracted into $10 \mathrm{~mL}$ of acetone for $24 \mathrm{~h}$ at $4{ }^{\circ} \mathrm{C}$, with sonication for the first $5 \mathrm{~min}$. Spectrophotometric analysis was conducted according to Strickland and Parsons (1972), substituting the equation from Jeffrey and Humphrey (1975).

\subsection{Estimation of primary production rates}

We assessed primary production (PP), both locally and globally, using the Vertically Generalized Production Model (VGPM) (Behrenfeld and Falkowski, 1997). The VGPM has been developed to estimate PP on a global scale based on satellite-derived Chl- $a$ concentration, temperature, and photosynthetically active radiation (PAR). To estimate local PP similar to Holm-Hansen (2004), we applied the VGPM according to Eq. (1):

$\mathrm{PP}=0.66125 \cdot P_{\mathrm{opt}}^{\mathrm{B}} \cdot \frac{E_{0}}{E_{0}+4.1} \cdot Z_{\mathrm{EU}} \cdot C_{\mathrm{Chl}} \cdot D_{\mathrm{irr}}$

with $C_{\mathrm{Chl}}$ being the measured surface concentrations of Chl$a\left(\mu \mathrm{g} \mathrm{L}^{-1}\right)$ at $1 \mathrm{~m}$ depth, $D_{\text {irr }}$ the photoperiod (in hours) calculated as a function of latitude and time of day, and $E_{\mathrm{o}}$ (mol quanta $\mathrm{m}^{2}$ ) the water surface PAR. We measured $E_{\mathrm{o}}$ a few centimetres below the water surface with an SQ-110 sensor (Apogee Instruments Inc.) mounted on a small float. We estimated the depth of the euphotic zone $\left(Z_{\mathrm{EU}}\right.$ in $\left.\mathrm{m}\right)$ from the measured Secchi depth according to Preisendorfer (1986). $P_{\mathrm{opt}}^{\mathrm{B}}$ can generally be described as a function of the water surface temperature according to Eq. (2) (Behrenfeld and Falkowski, 1997):

$$
\begin{aligned}
P_{\mathrm{opt}}^{\mathrm{B}} & =1.2956+0.2479 T+0.0617 T^{2}-0.0205 T^{3} \\
& +0.002462 T^{4}-1.348 \times 10^{-4} T^{5}+3.4132 \\
& \times 10^{-6} T^{6}-3.27 \times 10^{-8} T^{7}
\end{aligned}
$$

with $T\left({ }^{\circ} \mathrm{C}\right)$ being the measured water surface temperature. We have used similar approaches to assess both local and global PP to minimize uncertainties when extrapolating our results to the global scale.

Primary production rates were in good agreement with earlier ${ }^{14} \mathrm{C}$ measurements in the study areas (Table 1), except during the winter in Saanich Inlet. However, the primary production rate in Saanich Inlet can be highly variable, and in November and December 2008, we frequently observed elevated Chl- $a$ concentrations above $5 \mu \mathrm{L} \mathrm{L}^{-1}$ at the sampling site.

\subsection{Data analysis}

Statistical analyses were performed using Graphpad PRISM Version 5.1. Differences, null hypothesis testing, and correlation were considered to be significant when $p<0.05$, i.e., using the $95 \%$ confidence interval. We tested hypotheses with parametric or nonparametric tests, as stated. If required for parametric and ANOVA tests, the data were log transformed. Unless otherwise indicated, results are presented as means \pm 1 standard deviation. Enrichment factors (EF) were calculated as the ratio of concentrations in the SML sample to that of the corresponding subsurface bulk water sample.

For statistical data analysis, the concentrations and enrichments of surfactants have been categorized at different wind states (states 0 to 4 ), based on the PiersonMoskowitz sea spectrum (Pierson and Moscowitz, 1964). These wind states have been further merged into: low (state $0,0-2 \mathrm{~m} \mathrm{~s}^{-1}$ ), moderate (state $1-2,2-5 \mathrm{~m} \mathrm{~s}^{-1}$ ), and higher wind regimes (state $\geq 2.5,5-10 \mathrm{~m} \mathrm{~s}^{-1}$ ). Similarly, enrichments have been categorized in three trophic states based on Antoine et al. (1996): trophic state 1 represents oligotrophic waters with $\mathrm{PP}<0.4 \mathrm{~g} \mathrm{C} \mathrm{m}^{-2}$ day $^{-1}$; state 2 represents mesotrophic waters with PP ranging from 0.4 to $1.2 \mathrm{~g} \mathrm{C} \mathrm{m}^{-2} \mathrm{day}^{-1}$; and state 3 represents eutrophic waters with PP above $1.2 \mathrm{~g} \mathrm{C} \mathrm{m}^{-2} \mathrm{day}^{-1}$.

\subsection{Global mapping of ocean's SML coverage}

We choose the concentration of surfactants as the primary parameter, as it includes both dissolved and particulate fractions and therefore represents the total surface activity of the SML. Due to the fact that phytoplankton produces the majority of natural surfactants and therefore affects the local enrichment, we use the mean enrichments and concentrations of each trophic state and compare those with threshold values describing the intensity of the SML. The chosen threshold values of surfactant enrichments of 1.0, 1.5 and 2.0 are used to describe weakly, moderately and strongly SMLinfluenced ocean surfaces, respectively, and were obtained from the range of observed values.

The comparison of the mean enrichments of each trophic state with the chosen threshold enrichment values is illustrated in Fig. 2. The t-value for the comparison test is computed according to:

$t=\frac{\text { Sample Mean }- \text { Threshold Mean }}{\text { Standard Error }}$ (Motulsky, 2003)

If the result of the comparison showed a significant positive difference $(p<0.05)$, the regions on PP satellite-derived maps corresponding to the PP range of the trophic state are indicated with the intensity of influence described by the chosen threshold enrichment value. We use global ocean primary production maps estimated from SeaWIFS images using the VGPM model (Behrenfeld and Falkowski, 1997). The maps were provided by the Ocean Productivity Group at Oregon State University (http://www.science.oregonstate. edu/ocean.productivity).

Because we found little relationship between wind speed and microlayer surfactants under our sampling conditions (Fig. 3), we used wind only to set an upper limit for the 


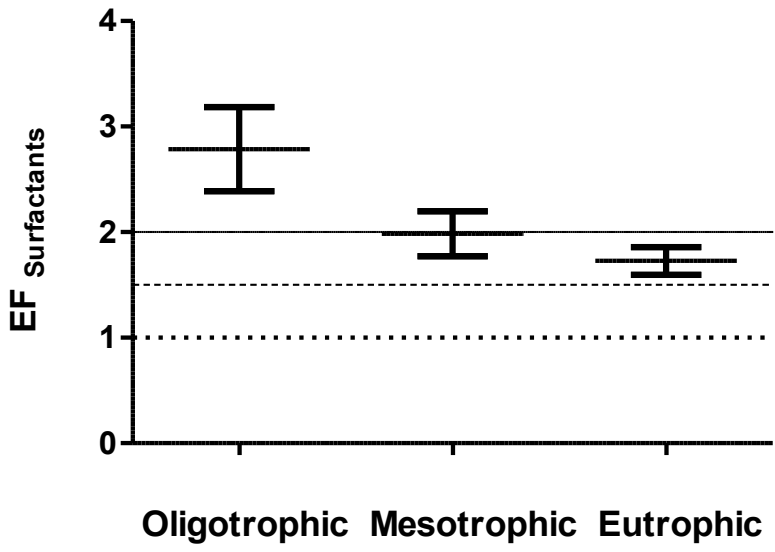

Fig. 2. Mean enrichment factor (EF) of surfactants at the three trophic states. The bars represent the $95 \%$ confidence interval of the mean. The chosen treshold enrichment values are indicated as lines: weak influence $(\cdots, \mathrm{EF}=1.0)$; moderate influence $(---$, $\mathrm{EF}=1.5)$; and stronger influence $(-, \mathrm{EF}=2.0)$.

presence of significant microlayer enrichment. Broecker et al. (1978) reported that an artificial surface film began to tear at a wind speed of $13 \mathrm{~m} \mathrm{~s}^{-1}$ during experiments in a linear wind-wave tunnel. Therefore, as a conservative estimate we considered all regions having a monthly average wind speed above $10 \mathrm{~m} \mathrm{~s}^{-1}$ as free of SML. We obtained monthly wind speed distributions from NCEP/NCAR Reanalysis Project (www.esrl.noaa.gov) (Kalnay et al., 1996). Those wind data are derived from various satellite measurements but not including scatterometer data. Scatterometer measurements are based on sea-surface roughness, and accumulation of surfactants can cause wave-damping and therefore affect scatterometer-derived wind data (Kalnay et al., 1996).

\section{Results}

Statistical data on surfactants and TDC enrichments at different trophic levels and wind regimes are presented in Table 2. Statistical data of surfactant enrichment in the different study areas are summarized in Table 3.

\subsection{Slick versus non-slick samples}

When the concentration of surfactants exceeds some presently unknown threshold value, SML become visible as smooth grey spots or stripes due to capillary wave-damping. Slick conditions can be observed as patches during increased supply of organic material to the SML, for example during high precipitation or coastal bloom events. We observed that the mean enrichment of surfactants in the SML during slick conditions $(3.6 \pm 3.4)$ was not significantly higher $(\mathrm{t}-$ test, $p<0.05)$ than during non-slick conditions $(1.9 \pm 1.0)$ in Saanich Inlet, but enrichments during slick conditions show

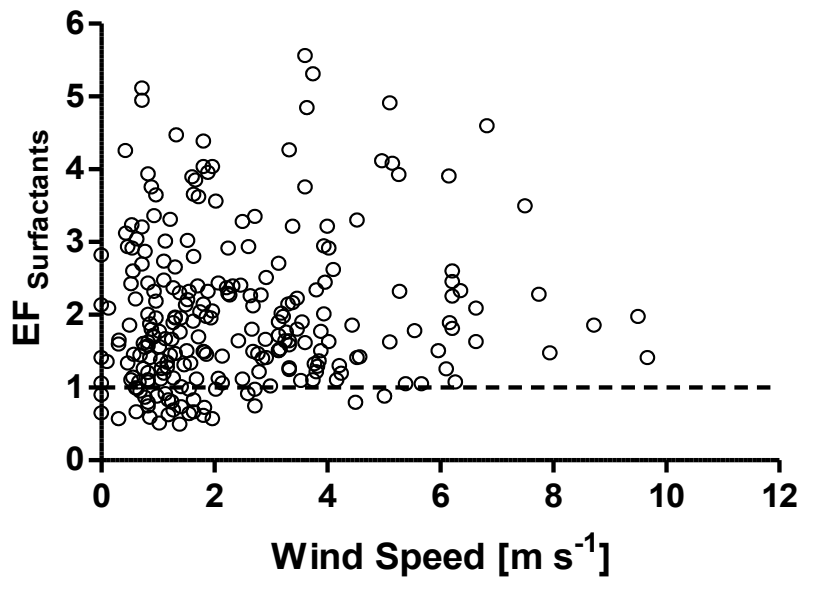

Fig. 3. Scatter plot of surfactant enrichment factor (EF) against observed wind speeds. Dashed line represent $\mathrm{EF}=1$.

very high variance. Slick samples were not consistently enriched in the presence of elevated surfactant concentrations in the bulk water during bloom conditions, but high surfactant enrichment was observed after rainfall events (maximum enrichment of 16), when wet deposition provided high loads of particulate matter to the SML, as visually observed. In the subsequent analysis, we excluded samples collected during slick conditions as such patchy conditions were mostly observed at nearshore sampling station (Saanich Inlet) and occur only after short-term events, such as the bloom peak or high precipitation events, typically occurring from fall to spring in British Columbia. For those reasons, slick conditions may be less representative, considering the objective of this study to map SML-influenced ocean surfaces on a global scale.

\subsection{Enrichment versus wind speed}

We found that the SML is consistently enriched in surfactants, relative to subsurface water, at wind speeds above $5 \mathrm{~m} \mathrm{~s}^{-1}$ (Fig. 3). At low $\left(0-2 \mathrm{~m} \mathrm{~s}^{-1}\right)$ and moderate wind speeds $\left(2-5 \mathrm{~m} \mathrm{~s}^{-1}\right) 21 \%$ and $9 \%$ of the observations showed a depletion of surfactants in the SML respectively, i.e., EF less than 1.

Occasionally, in oceanic SML we observed surfactant concentrations above $1000 \mu \mathrm{g} \mathrm{Teq} \mathrm{L}^{-1}$, which is more typical for coastal waters. These observations were in the presence of breaking waves at wind speeds above $5 \mathrm{~m} \mathrm{~s}^{-1}$. The mean enrichments between the three wind regimes are not significantly different using wind data recorded during sampling. However, we observe a significant difference (OneWay ANOVA, $p=0.0027$ ) using average wind speeds recorded for six hours prior to sampling, indicating that the wind history affects enrichment processes. Based on the six hour wind record, the mean enrichments at the low, moderate and high wind regimes were $1.7 \pm 1.1,2.3 \pm 1.4$ and $2.1 \pm 1.1$, 
Table 2. Statistical data on enrichment factors (EF) of surfactants and total dissolved carbohydrates (TDC) in the microlayer at different wind regimes and trophic states.

\begin{tabular}{l|ccc|ccc}
\hline Wind Regimes & Low & $\begin{array}{c}\mathrm{EF}_{\text {Surfactants }} \\
\text { Moderate }\end{array}$ & High & Low & $\begin{array}{c}\text { EF } \\
\text { MDC }\end{array}$ & High \\
\hline$n^{\mathrm{a}}$ & 151 & 91 & 32 & 116 & 74 & 25 \\
Min & 0.5 & 0.6 & 1.1 & 0.3 & 0.4 & 0.6 \\
Max & 6.8 & 5.6 & 4.9 & 4.7 & 5.3 & 2.2 \\
Mean \pm sd & $2.0 \pm 1.2$ & $2.1 \pm 1.0$ & $2.2 \pm 1.1$ & $1.4 \pm 0.7$ & $1.4 \pm 0.8$ & $1.2 \pm 0.4$ \\
Lower 95\% CI & 1.8 & 1.8 & 1.8 & 1.3 & 1.2 & 1.0 \\
Upper 95\% CI & 2.2 & 2.3 & 2.6 & 1.5 & 1.6 & 1.3 \\
Median 25 & 1.1 & 1.4 & 1.5 & 1.0 & 1.0 & 1.1 \\
Median 50 & 1.7 & 1.8 & 1.8 & 1.2 & 1.3 & 1.1 \\
Median 75 & 2.5 & 2.4 & 2.4 & 1.6 & 1.5 & 1.3 \\
\hline & & $\mathrm{EF}_{\text {Surfactants }}$ & & & EF & \\
Trophic States & Oligo & Meso & Eutrophic & Oligo & Meso & Eutrophic \\
\hline$n^{\text {a }}$ & 38 & 93 & 143 & 17 & 69 & 124 \\
Min & 1.3 & 0.5 & 0.5 & 0.4 & 0.5 & 0.3 \\
Max & 5.6 & 4.6 & 4.0 & 2.5 & 4.2 & 5.3 \\
Mean \pm sd & $2.7 \pm 1.3$ & $2.0 \pm 1.0$ & $1.7 \pm 0.8$ & $1.2 \pm 0.6$ & $1.4 \pm 0.6$ & $1.4 \pm 0.8$ \\
Lower 95\% CI & 2.3 & 1.8 & 1.7 & 0.9 & 1.3 & 1.2 \\
Upper 95\% CI & 3.1 & 2.2 & 2.0 & 1.5 & 1.6 & 1.5 \\
Median 25 & 1.7 & 1.2 & 1.1 & 0.8 & 1.0 & 1.0 \\
Median 50 & 2.3 & 1.8 & 1.6 & 1.1 & 1.3 & 1.2 \\
Median 75 & 3.6 & 2.5 & 2.2 & 1.5 & 1.6 & 1.5 \\
\hline & & & & & & \\
\hline
\end{tabular}

Number of observations $(n)$, minimum (Min), maximum (Max), standard deviation (sd)

a non-slick samples only

${ }^{\mathrm{b}}$ Confidence interval of the mean

respectively; significantly lower for the low wind regime than for the moderate and higher wind regimes (Tukey multiple comparison test). However, we did not observe significant differences in the surfactant concentrations in the SML between the wind regimes based on the instantaneous and six hour wind record.

In contrast to surfactants, total dissolved carbohydrates (TDC) were slightly depleted under the higher wind regime compared with the lower wind regimes (Table 2). Within each wind regime about $25 \%$ of the observations indicated a depletion of TDC. The mean enrichments among the wind regimes are not significantly different for either the instant or the six hour back-averaged wind records. Enrichment of TDC are significantly lower $(p<0.001)$ than the corresponding mean enrichments of surfactants.

Although the mean enrichments between the wind regimes are not significantly different, a fundamental observation from this study is that surfactants were always enriched under the higher wind regimes (i.e., $5-10 \mathrm{~m} \mathrm{~s}^{-1}$ ) we were able to sample.

\subsection{Enrichment versus PP}

Our observations show that the mean surfactant enrichment in the SML diminishes with increasing primary productivity. We categorized the log-transformed enrichment data into the three trophic states (Fig. 2) and found that the mean enrichment in oligotrophic waters differs very significantly from meso- and eutrophic waters $(p<0.001$, one way ANOVA, Tukey's multiple comparison). A significant difference ( $p=$ 0.0251 ) still remains if only enrichments obtained during the low wind regimes are considered in order to minimize effect of wind speed in the enrichment. Regression analysis, on the other hand, did not show a significant relationship between the enrichment of surfactants or TDC and the primary production, but the following supports our more general observation of diminishing surfactant enrichment with increasing primary productivity.

The surfactant enrichment in the oligotrophic Labrador Fjords (AC5, Fig. 1) $(\mathrm{EF}=4.1 \pm 1.0, n=4)$ was significantly higher $(p=0.0107)$ than for the eutrophic fjord, Saanich Inlet (SI, Fig. 1) $(\mathrm{EF}=2.3 \pm 1.1, n=17)$, during the same season (November) and under similar wind conditions. During the summer season (June to September), the surfactant enrichment in the SML was greater in the oceanic regions 
Table 3. Statistical data on enrichment factors of surfactants in the microlayer at different study areas.

\begin{tabular}{|c|c|c|c|c|c|c|c|c|}
\hline & \multirow{2}{*}{$\begin{array}{c}\text { Saanich Inlet (SI) } \\
\text { Nearshore }\end{array}$} & \multicolumn{2}{|c|}{ Vancouver Island (VI) } & \multirow{2}{*}{$\begin{array}{c}\text { California (CA) } \\
\text { Offshore }\end{array}$} & \multicolumn{2}{|c|}{ North Pacific (NP) } & \multicolumn{2}{|c|}{ subtrop. NorthPacific (HI) } \\
\hline & & Nearshore & Offshore & & Offshore & Oceanic & Offshore & Oceanic \\
\hline$n^{\mathrm{a}}$ & 167 & 5 & 7 & 22 & 5 & 14 & 12 & 11 \\
\hline Max & 5.6 & 4.5 & 3.5 & 5.0 & 2.5 & 5.3 & 4.4 & 5.6 \\
\hline Mean \pm sd & $1.9 \pm 1.0$ & $2.5 \pm 1.3$ & $1.8 \pm 0.9$ & $1.8 \pm 1.1$ & $1.7 \pm 0.6$ & $2.9 \pm 1.3$ & $1.7 \pm 1.1$ & $2.3 \pm 1.2$ \\
\hline Lower $95 \% \mathrm{CI}^{\mathrm{b}}$ & 1.7 & 0.8 & 0.9 & 1.3 & 0.9 & 2.4 & 1.0 & 1.5 \\
\hline Median 50 & 1.6 & 2.5 & 1.7 & 1.7 & 1.9 & 2.5 & 1.3 & 1.9 \\
\hline Median 75 & 2.3 & 3.5 & 2.1 & 2.3 & 2.2 & 3.9 & 2.2 & 2.6 \\
\hline
\end{tabular}

\begin{tabular}{|c|c|c|c|c|c|c|}
\hline & \multicolumn{3}{|c|}{ Arctic (AC) } & \multicolumn{3}{|c|}{ All data } \\
\hline & Nearshore & Offshore & Oceanic & Nearshore & Offshore & Oceanic \\
\hline$n^{\mathrm{a}}$ & 4 & 9 & 9 & 176 & 54 & 44 \\
\hline Min & 1.4 & 3.2 & 1.5 & 0.5 & 0.6 & 1.1 \\
\hline Max & 5.6 & 5.9 & 2.6 & 5.9 & 5.0 & 5.6 \\
\hline Mean $\pm \mathrm{sd}$ & $4.8 \pm 1.1$ & $2.0 \pm 0.4$ & $2.7 \pm 1.3$ & $1.9 \pm 1.1$ & $1.8 \pm 0.9$ & $2.7 \pm 1.3$ \\
\hline Lower $95 \% \mathrm{CI}^{\mathrm{b}}$ & 1.7 & 3.0 & 1.7 & 1.8 & 1.6 & 2.3 \\
\hline Upper $95 \% \mathrm{CI}^{\mathrm{b}}$ & 3.8 & 6.6 & 2.3 & 2.1 & 2.1 & 3.1 \\
\hline Median 25 & 1.7 & 3.6 & 1.5 & 1.1 & 1.1 & 1.8 \\
\hline Median 50 & 2.3 & 5.0 & 2.2 & 1.6 & 1.7 & 2.3 \\
\hline Median 75 & 3.4 & 5.7 & 2.4 & 2.4 & 2.3 & 3.6 \\
\hline
\end{tabular}

Number of observations ( $n$ ), minimum (Min), maximum (Max), standard deviation (sd)

Nearshore: within $2 \mathrm{~km}$ to coast; Offshore: $2-20 \mathrm{~km}$ from coast; Oceanic: further than $20 \mathrm{~km}$ off the coast

a non-slick samples only

$\mathrm{b}$ Confidence interval of the mean

(NP and HI, Fig. 1) than at the near-shore site (Saanich Inlet, SI), with mean enrichments of $2.5 \pm 1.3$ and $1.9 \pm 0.6$, respectively ( $p=0.0351, \mathrm{t}$-test). On the other hand, the difference in surfactant enrichments was insignificant between tropical (HI) and polar (AC) regions, both characterized by oligotrophic conditions indicating that surfactant enrichment was independent of location. Surfactant enrichments at the oceanic study sites were consistently above unity (Fig. 4). In addition, above bulk water concentrations of $600 \mu \mathrm{g} \mathrm{Teq} \mathrm{L}^{-1}$ we found only relatively low surfactant enrichments not exceeding 2.7 (Fig. 5). Bulk water surfactant concentrations typically exceed this level under bloom conditions.

We saw a seasonal trend in the enrichment of phytoplankton-exudated TDC in Saanich Inlet (Fig. 6). No similar trend was found for surfactants, which probably include inputs from increased terrestrial runoff and enhanced atmospheric deposition during the winter months. As shown in Fig. 6, when PP was at its highest, the mean TDC enrichment was low ( $E F=0.9$, August 2008) but increased during the less-productive bloom in the fall $(\mathrm{EF}=1.8$, November 2008). The highest mean enrichment of TDC $(E F=2.3)$ was observed during the period of low PP (January 2009) but decreased again to $\mathrm{EF}=0.7$ with the onset and development of the spring bloom (February 2009 to May 2009). The differences in the monthly mean enrichments of TDC were very significant.

Overall, we found that low productivity and moderate to high wind speeds lead to higher enrichments of natural surfactants in the SML.

\subsection{Surfactant concentrations in the SML versus PP}

Similar to enrichment factors, we have categorized concentrations of surfactants in the SML into the three PP categories described in Sect. 2.6. We found that the mean concentration increases with increasing PP (Fig. 7), in agreement with expectations. The mean concentrations $( \pm 95 \%$ confidence interval) for oligotrophic, mesotrophic and eutrophic waters were $320 \pm 66 \mu \mathrm{g} \mathrm{Teq} \mathrm{L}{ }^{-1}, 502 \pm 107 \mu \mathrm{g} \mathrm{Teq} \mathrm{L}^{-1}$ and $663 \pm$ $77 \mu \mathrm{g}$ Teq $\mathrm{L}^{-1}$, respectively. The nonparametric Kruskal Wallis test with a post comparison (Dunn test) showed that the medians of the concentrations were very significantly different $(p<0.05)$ between all three PP categories. 


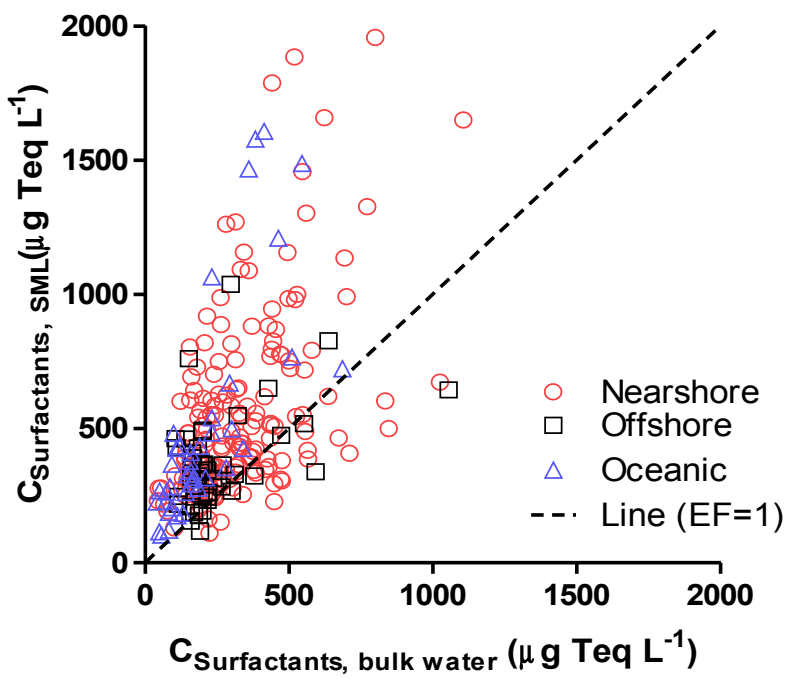

Fig. 4. SML concentration versus bulk water concentrations of surfactants in nearshore (within $2 \mathrm{~km}$ from coast), (2-20 km from coast) and open ocean (further than $20 \mathrm{~km}$ off the coast). Broken line indicates equal concentrations in SML and bulk water (i.e. $\mathrm{EF}=1)$.

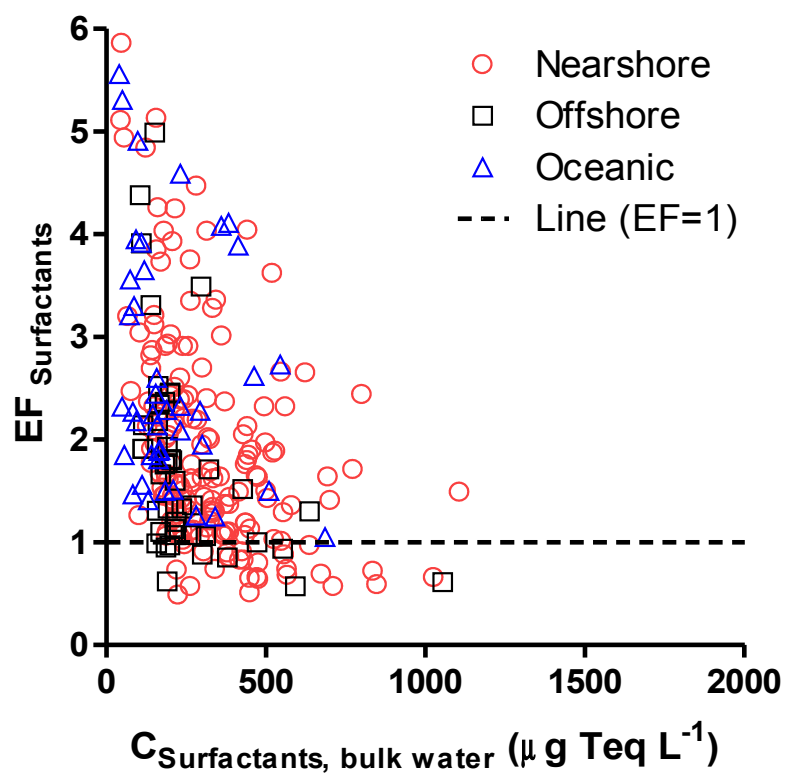

Fig. 5. Diminshing surfactant enrichment factors (EFs) with increasing bulk water concentration in nearshore (within $2 \mathrm{~km}$ of coast), offshore (2-20 km from the coast), and open ocean (further than $20 \mathrm{~km}$ from the coast).

\section{Discussions}

Our results suggest that the ocean's surface microlayer is more strongly enriched in surfactants in oceanic regions with low productivity than in more productive coastal regions (except some slicks), despite earlier assumptions that surfactant enrichments increase with primary production (Asher, 1997;

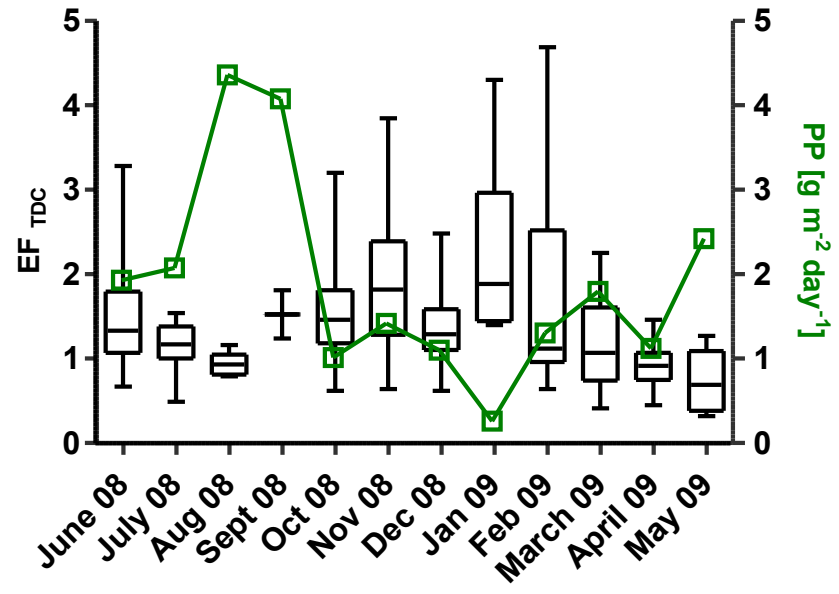

Fig. 6. Seasonal time series of the monthly average enrichment factors $(\mathrm{EF})$ of total dissolved carbohydrates in Saanich Inlet. Monthly averaged primary production (PP) is represented by $\square$ symbols.

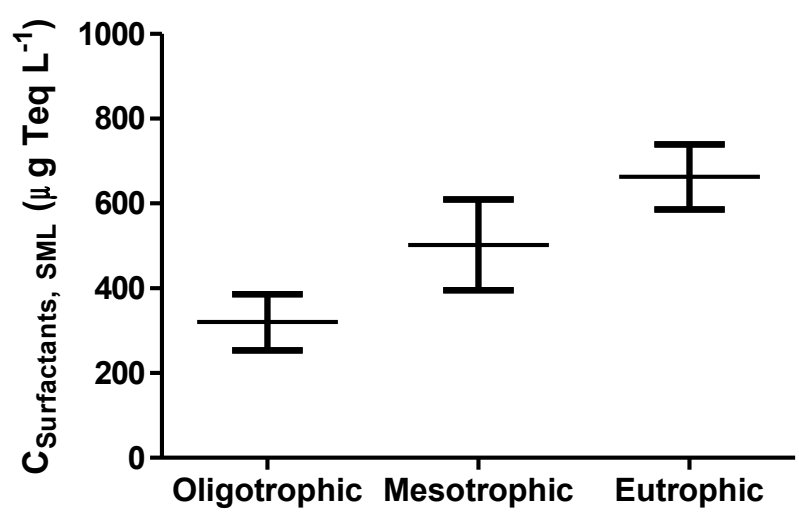

Fig. 7. Mean concentrations of surfactants in the SML at the three trophic states. The bars represent the $95 \%$ confidence intervals of the means.

Tsai and Liu, 2003). For example, Tsai and Lui identified wide regions between $30^{\circ} \mathrm{N}$ and $30^{\circ} \mathrm{S}$ as largely surfactantfree, whereas our field observations suggest that SML surfactant enrichments may actually be quite strong in those oligotrophic regions. Our results indicate that the enrichment factors within a trophic state seems to be independent of the location.

\subsection{Evidence for microlayer enrichment at higher wind speeds}

In confirmation of previous studies, we found that surfactant enrichment in the SML can persist at wind speeds up to $9.5 \mathrm{~m} \mathrm{~s}^{-1}$. Reinthaler et al. (2008) reported enrichment of DOC and amino acids at wind speeds exceeding $7.5 \mathrm{~m} \mathrm{~s}^{-1}$. Indeed, they observed the second highest enrichments of DOC $(E F=2.1)$ and dissolved free amino acids $(E F=206)$ at the site with the highest wind speed (i.e., $9.7 \mathrm{~m} \mathrm{~s}^{-1}$ ). 
Table 4. Statistical data on surfactant concentrations in the microlayer at different wind regimes and trophic states.

\begin{tabular}{|c|c|c|c|c|c|c|}
\hline & \multicolumn{3}{|c|}{ Wind Regimes } & \multicolumn{3}{|c|}{ Trophic States } \\
\hline & Low & Moderate & High & Oligo & Meso & Eutrophic \\
\hline$n^{\mathrm{a}}$ & 151 & 91 & 32 & 38 & 93 & 143 \\
\hline Min & 110 & 115 & 104 & 104 & 110 & 129 \\
\hline $\operatorname{Max}$ & 4984 & 1955 & 1578 & 1468 & 4984 & 2868 \\
\hline Mean \pm sd & $624 \pm 588$ & $474 \pm 286$ & $498 \pm 330$ & $320 \pm 215$ & $502 \pm 532$ & $663 \pm 476$ \\
\hline Lower $95 \% \mathrm{CI}^{\mathrm{b}}$ & 532 & 415 & 390 & 254 & 395 & 586 \\
\hline Upper $95 \% \mathrm{CI}^{\mathrm{b}}$ & 717 & 532 & 607 & 386 & 610 & 740 \\
\hline Median 25 & 313 & 270 & 306 & 217 & 284 & 357 \\
\hline Median 50 & 436 & 371 & 401 & 277 & 386 & 503 \\
\hline Median 75 & 653 & 619 & 564 & 356 & 540 & 780 \\
\hline
\end{tabular}

Number of observations ( $n$ ), minimum (Min), maximum (Max), standard deviation (sd)

a non-slick samples only

${ }^{\mathrm{b}}$ Confidence interval of the mean

Kuznetsova et al. (2004) and Carlson (1983) detected enrichment of both amino acids and DOC at wind speeds of up to about $8 \mathrm{~m} \mathrm{~s}^{-1}$.

For obvious reasons, the SML is temporarily disrupted in the presence of breaking waves, dispersing SML material into the bulk water. In both laboratory (Dragćević and Pravdić, 1981) and field (Williams et al., 1986) experiments, surface films appear to reform within seconds after disruption. In the presence of breaking waves, dispersed SML materials adsorb rapidly to the surface of the rising air bubbles, and therefore, bubble plumes may be the most important transport vector for surface-active material to the SML (Liss, 1975; Stefan and Szeri, 1999). When the bubble bursts at the sea-surface, only a fraction of attached organic matter is ejected into the air as aerosols, whereas the remainder is adsorbed on the surface to reform the SML (Liss, 1975). The foamy patches frequently observed after waves breaking are a consequence of surfactant scavenging by rising air bubbles. Along those lines, we also found that windspeed history is more important than instantaneous winds to microlayer enrichment, as also reported by Obernosterer et al. (2008). Breaking waves start to appear at wind speeds of 2.5 to $3.5 \mathrm{~m} \mathrm{~s}^{-1}$ (Hwang and Sletten, 2008) and therefore, are not present in our "low" wind regime. This further supports our observation that breaking waves can facilitate the formation of the SML through rising bubble plumes returning dispersed surfactants to the surface.

Besides acting as transport vector, it is reasonable to assume that bubbles can affect the composition of materials accumulating in the SML. Johnson and Cooke (1980) pointed out that the adsorption of surface-active compounds is selective, and compounds with higher surface activity have the highest potential to be scavenged and brought to the surface. Because even clean bubbles quickly become covered with surfactant while rising (Stefan and Szeri, 1999), globules of material may drop off the bottom of the bubbles, which could fractionate the material, leaving the most surface-active substances on the bubbles (GESAMP, 1995).

Furthermore, Carlson (1993) provided evidence that constant compression and dilation of the SML can facilitate particle aggregation and condensation of high molecular weight (HMW) material from surfactants, including dissolved carbohydrates. Such enhanced particle aggregation and condensation of HMW DOM are likely to be important in the formation and stabilization of the SML (Hunter, 1980). Those processes may be more significant in oceanic regions through more intense compression and dilation driven by wave action.

We found no evidence of significant relationships between surfactant concentration in the SML or its enrichment, and wind speed. Similarly, Carlson (1983) reported no relationship between DOC enrichment and wind state. On the other hand, Lui and Dickhut (1998) found an exponential relationship between wind speed and excess concentration of suspended particles in the SML of river estuaries. Obernosterer et al. (2008) reported a negative linear relationship between the six hour wind speed records and the enrichment of particulate organic carbon (POC) and nitrogen (PON) in the South Atlantic, but only for a narrow wind range of 0.5 to $2.5 \mathrm{~m} \mathrm{~s}^{-1}$. At higher wind speeds, bubbling and turbulence may lead to more complex enrichment processes, confounding any simple relationship between enrichment and wind speed. Furthermore, we measured total surfactants (i.e., the dissolved and particulate fractions together), which could have masked any relationship between wind speed and particulate matter enrichment. It should be also noted that the thickness of the SML collected using the glass plate technique is affected by wind states (Carlson, 1982). Obernosterer (2008) used a screen sampler, which collects thicker layers of more consistent thickness $(200-400 \mu \mathrm{m})$, independent of wind speeds. Sampling of various sites with different conditions and characteristics (nearshore, offshore, and 
Table 5. Statistical data on the concentration (in $\mu \mathrm{g} \mathrm{Teq} \mathrm{L}^{-1}$ ) of surfactants in the microlayer at different study areas.

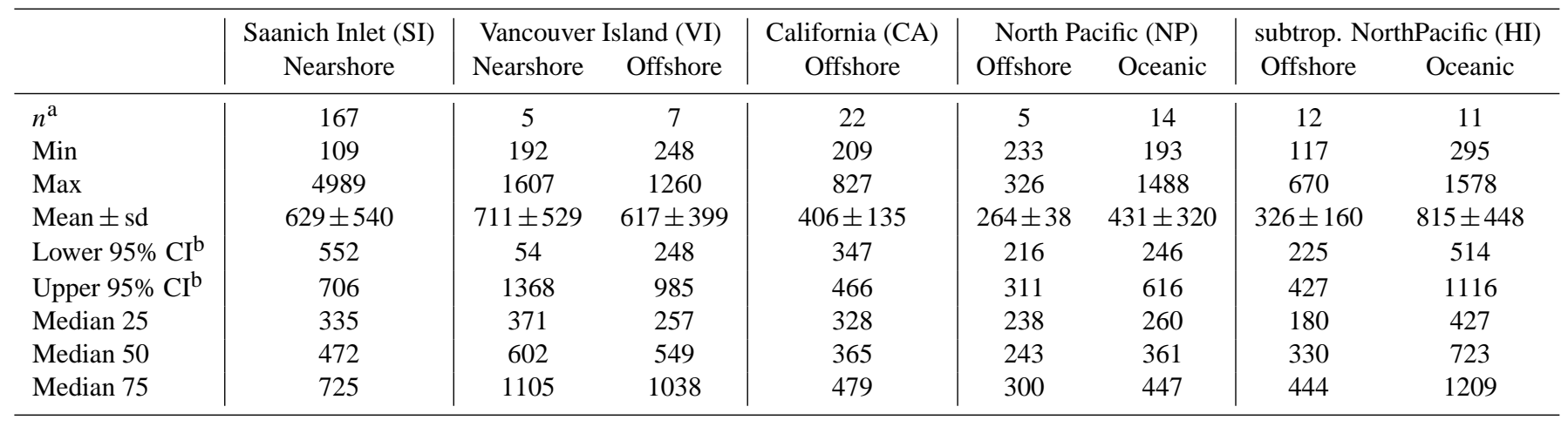

\begin{tabular}{|c|c|c|c|c|c|c|}
\hline & \multicolumn{3}{|c|}{ Arctic (AC) } & \multicolumn{3}{|c|}{ All data } \\
\hline & Nearshore & Offshore & Oceanic & Nearshore & Offshore & Oceanic \\
\hline$n^{\mathrm{a}}$ & 4 & 9 & 9 & 176 & 54 & 44 \\
\hline Min & 216 & 174 & 104 & 109 & 117 & 104 \\
\hline Max & 277 & 410 & 387 & 4989 & 1260 & 1578 \\
\hline Mean $\pm \mathrm{sd}$ & $247 \pm 28$ & $278 \pm 77$ & $211 \pm 90$ & $618 \pm 532$ & $376 \pm 203$ & $497 \pm 401$ \\
\hline Lower $95 \% \mathrm{CI}^{\mathrm{b}}$ & 202 & 219 & 142 & 543 & 321 & 357 \\
\hline Upper $95 \% \mathrm{CI}^{\mathrm{b}}$ & 291 & 337 & 280 & 693 & 432 & 637 \\
\hline Median 25 & 220 & 197 & 119 & 328 & 261 & 232 \\
\hline Median 50 & 247 & 284 & 227 & 471 & 329 & 373 \\
\hline Median 75 & 273 & 324 & 270 & 709 & 428 & 510 \\
\hline
\end{tabular}

Number of observations ( $n$ ), minimum (Min), maximum (Max), standard deviation (sd)

Nearshore: within $2 \mathrm{~km}$ to coast; Offshore: $2-20 \mathrm{~km}$ from coast; Oceanic: further than $20 \mathrm{~km}$ off the coast

a non-slick samples only

oceanic) during Carlson's and our studies likely contributes to our observed lack of a significant correlation between enrichment and wind speed.

However, one concrete observation remains from our study: enrichment always occurs at wind speeds higher than $5 \mathrm{~m} \mathrm{~s}^{-1}$.

\subsection{Microlayer at different trophic states}

We found that the surfactant enrichments in the SML are higher in oligotrophic waters than in mesotrophic and eutrophic waters. The difference in those enrichments between regions with low and moderate/high primary productivity is small $(\mathrm{EF}=2.8$ vs. $\mathrm{EF}=1.8)$ but statistically significant $(p=0.01)$. The observation is supported by the seasonal variations in the enrichment of carbohydrates, metabolic exudates by phytoplankton, in Saanich Inlet, with the highest enrichments during seasons of low productivity and vice versa (Fig. 6).

We suggest that the observation of diminishing enrichments with increasing productivity is a general phenomenon, as it has been observed in several other studies for DOM enrichment in sea- and freshwaters (Carl- son, 1983; Södergren, 1987; Zhou et al., 1998; HillbrichtIlkowska and Kostrzewka-Szlakowska, 2004; KostrzewkaSzlakowska, 2005; Baastrup-Spohr and Staehr, 2009; Cunliffe et al., 2009). Correlations between enrichment factors and primary production or chl- $a$ suffer from a lack of significance, as such simple correlations are confounded by multiple and complex enrichment processes. However, we suggest that the general observation of diminishing enrichments with increasing productivity is an obvious approach to approximate SML coverage based on primary productivity maps (Sect. 4.3). Conditions responsible for the differences in the enrichment between the trophic states are the subject of the following discussion.

Carlson (1983) reported the first observations of diminishing DOC enrichments from oceanic to productive coastal waters. He suggested that increased solubility of potentially surface-active material with increasing DOC concentrations in bulk water could cause losses of material prone to accumulate in the SML leading to lower enrichments with increasing productivity. Different DOM composition between trophic states may not only lead to different tendencies of material to accumulate in the SML, but also determine the fate of enriched DOM. For example, dissolved lignin in 


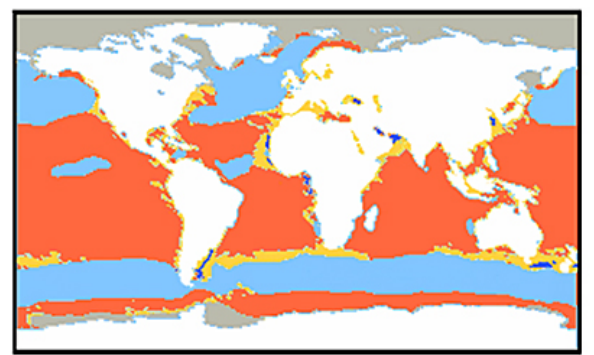

a) Spring

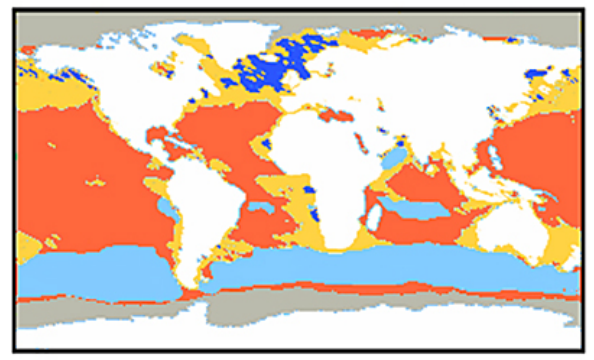

c) Fall

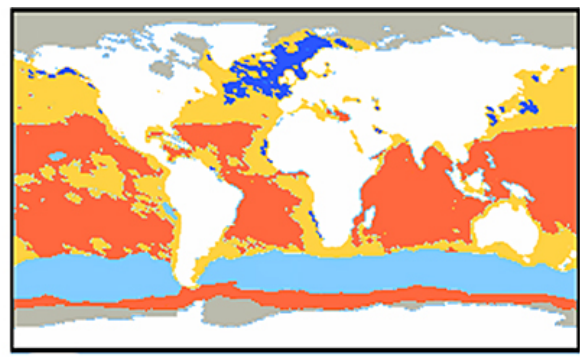

b) Summer

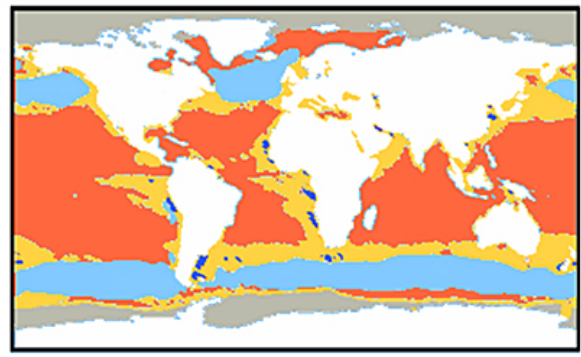

d) Winter

Fig. 8. Global maps of mean concentrations of surfactants in the SML ( $\pm 95 \%$ confidence interval of mean) and their enrichment factors (EF) for (a) April-June, (b) July-September, (c) October-December and (d) January-March. Red: $320 \pm 66 \mu \mathrm{g} \mathrm{Teq} \mathrm{L} \mathrm{L}^{-1}$, EF $>2$; yellow: $502 \pm 107 \mu \mathrm{g} \mathrm{Teq} \mathrm{L}^{-1}, 2>\mathrm{EF}>1.5$; dark blue: $663 \pm 77 \mu \mathrm{g} \mathrm{Teq} \mathrm{L}^{-1}, 1.5>\mathrm{EF}>1.0$; light blue: no enrichment.

open ocean waters was significantly more resistant to photochemical alteration than terrestrial lignin in river waters (Opsahl and Benner, 1998). In an earlier study, we showed that transparent exopolymer particles (TEP), abundant gellike particles in the ocean, are significantly enriched in the open ocean (chl- $a<2 \mu \mathrm{g} \mathrm{L}^{-1}$ ) but not in coastal waters (chl$a>5 \mu \mathrm{g} \mathrm{L}^{-1}$ ) (Wurl and Holmes, 2008). Azam and Malfatti (2007) suggested that depending on their surface properties, gels may adsorb DOM components from the dissolved phase. For this reason, it is possible that TEPs in oligotrophic SML may draw proportionately more DOM into the SML. On the other hand, we suggest that eutrophic conditions in bulk water represent a very complex system in which DOM is more rapidly recycled, transformed, or adsorbed on abundant cell surfaces before it can reach the SML.

Carlson (1983) further suggests that differences in enrichments between oceanic and coastal waters may reflect differences in SML accumulation or removal processes. We agree with Carlson (1983) that it is unlikely that the intensity of near-surface advective and diffusive processes in oligotrophic waters (e.g. oceanic) are sufficiently greater than in meso- or eutrophic waters to cause larger enrichments in low productivity regions. Zhou and Mopper (1997) observed deposition of DOM onto the SML from the atmosphere, but there is no reason to argue that this process would be significantly larger in oligotrophic regions. More likely, the removal of SML material through the formation of particulate matter sinking down into the bulkwater may be more effective in more productive waters. For example, Wheeler (1975) was able to observe particle formation in the SML by compression of water surfaces in coastal water, but not in oceanic water. Sholkovitz et al. (1978) suggested that terrestrial materials can contribute to particle formation, and such material would have been abundantly available at the sampling site in Saanich Inlet, which we are using in this study as a representative for eutrophic conditions, in general.

Surfactant production by bacteria and/or zooplankton (i.e., non-chlorophyll containing organisms) may become more important in oligotrophic conditions. Recently, Jiao et al. (2010) highlighted the importance of the bacterial production of refractory material, whereas Kujawinski et al. (2002) provided evidence of grazing-mediated surface-active DOM production. Both processes may become the major source of surface-active material under oligotrophic conditions. Jiao et al. (2010) also pointed out that recalcitrant DOM can be released during bacterial degradation of POM, which is typically enriched even in oceanic microlayers by factors of up to 40 (Carlson, 1983).

\subsection{Global maps}

Global maps of SML surfactant enrichment, as derived in Sect. 2.7, above, are presented in Fig. 8. Similar approaches have been used by Asher (1997) and Tsai and Lui (2003), but with somewhat arbitrary threshold values and no consideration of wind speeds.

The maps represent both the SML surfactant concentrations and their enrichments, the ratio of the surfactant 
Table 6. Literature values of oceanic enrichments of organic material in the microlayer.

\begin{tabular}{lcccc}
\hline Reference & Parameter & Enrichment & Location & \\
\hline \multirow{2}{*}{ Sieburth et al. (1976) } & DOC & $1.6 \pm 0.3$ & Atlantic Ocean & oceanic \\
& TDC & $2.0 \pm 0.9$ & & \\
\hline \multirow{2}{*}{ Williams et al. (1986) } & DOC & $1.4 \pm 0.1$ & & \\
& TDC & $1.6 \pm 0.2$ & North Pacific & oceanic \\
& POC & $3.7 \pm 1.6$ & & \\
\hline \multirow{2}{*}{ Frew et al. (2002) } & CDOM & 1.7 and 1.5 & Atlantic Ocean & $\begin{array}{l}\text { oceanic } \\
\text { offshore }\end{array}$ \\
\hline Calace et al. (2007) & Fulvic acids & $4.8 \pm 1.9$ & Gerlache Strait & offshore \\
\hline \multirow{2}{*}{ Reinthaler et al. (2008) } & \multirow{2}{*}{ DOC } & $1.5 \pm 0.3$ & Atlantic Ocean & oceanic \\
& & $1.8 \pm 0.3$ & Mediterrean Sea & oceanic \\
\hline
\end{tabular}

concentration in the SML to that in the corresponding subsurface water. The concentration distributions are the inverse of the enrichment distributions; that is, the areas with the lowest concentrations of surfactant in the microlayer have the highest enrichments and vice versa. The maps indicate that the North Atlantic (north of $30^{\circ} \mathrm{N}$ ) is not strongly influenced by SML surfactant enrichment, despite the large spring and summer phytoplankton blooms with PP rates that can exceed $1 \mathrm{~g} \mathrm{C} \mathrm{m}^{-2}$ day $^{-1}$ (Siegel et al., 2002). Strong winds exceeding $11-12 \mathrm{~m} \mathrm{~s}^{-1}$ are likely to disrupt the SML in the North Atlantic during seasons of lower productivity (i.e., Northern Hemisphere fall and winter). Similar patterns can be seen in the North Pacific, although weaker enrichments are only observed along the southern coastline of Alaska, and most of the region still has moderate enrichments during spring and summer, consistent with the mesotrophic conditions reported by Harrison et al. (1999). Tsai and Lui (2003) derived substantial surfactant enrichments for the North Atlantic and North Pacific during fall, but they did not account for the high winds during that period.

The maps indicate that tropical regions, within $30^{\circ} \mathrm{N}-$ $30^{\circ} \mathrm{S}$, may have strong SML enrichments, except in the coastal upwelling areas off South America and West Africa. In particular, the moderate enrichments within the NW African upwelling system persist throughout the year, which is consistent with the observations from Tsai and Liu (2003). Although upwelling is generally restricted to a narrow coastal band, the upwelled water can be transported up to $450 \mathrm{~km}$ offshore in the form of large filaments and eddies (Zonnefeld et al., 2010), extending the areas of moderate enrichment. In contrast, we derived stronger enrichments during January to March along the central and SW African coast, resulting from lower productivity.

The Indian Ocean is widely affected by stronger enrichments, with lower enrichments along coastal areas. During the southwest monsoon (July to September), high winds dis- rupt SML formation in the central Indian Ocean and offshore Saudi Arabia.

The Southern Ocean is mainly free of SML surfactant enrichment due to high winds. Surfactant enrichment in the SML during the local summer season (January to March) was likely overestimated by Tsai and Lui (2003), as they did not consider the wind effect in their study. Circumpolar narrow areas of enrichment just north of $30^{\circ} \mathrm{S}$ are the result of diminishing winds.

\subsection{Implications for air-sea gas exchange}

In this study, we have shown that the ocean's surface microlayer is likely more widely influenced by surfactant enrichments than earlier studies suggested (Asher, 1997; Tsai and Lui, 2003). This discovery has implications for the assessment of air-sea exchange of greenhouse gases affecting the Earth's radiation budget. Tsai and Liu (2003) reported that surfactant films can reduce the global annual net flux of $\mathrm{CO}_{2}$ by 20 to $50 \%$, using primary production rates of 0.5 and $0.8 \mathrm{~g} \mathrm{C} \mathrm{m}^{-2} \mathrm{day}^{-1}$ as the postulated thresholds for two scenarios of the ocean's coverage with surfactant films. As discussed in the previous section, those threshold values were based on an assumption that surfactant enrichment in the SML increases with primary productivity, but our experimental data showed an opposite effect, implying higher surfactant enrichments in regions with low primary productivity. For this reason, the global $\mathrm{CO}_{2}$ flux reduction may occur to a higher extent than presented by Tsai and Liu (2003) (Fig. 9 of their report).

Our data also suggest that bubble-mediated upward transport of surfactants re-form the SML rapidly, and Asher (1996) demonstrated through experiments in a whitecap simulation tank that soluble surfactants (e.g., carbohydrates) inhibit gas transfer even when waves break. Asher (1996) showed that the presence of soluble surfactant reduced the liquid-phase transfer velocities. They found a 
reduction for both soluble $\left(\mathrm{CO}_{2}\right)$ and insoluble $(\mathrm{He})$ gases, even at the highest fractional area bubble coverage. Therefore, we conclude that the SML can have a significant effect on air-sea gas exchange rates on a global scale.

Although we have known that surfactant films affect air-sea gas exchange rates for several decades (Broecker et al., 1978; Goldman et al., 1988; Frew et al., 2002), no parametrization of air-sea gas exchange rates includes the concentration of surfactants in the SML. Broecker et al. (1978) included the effects of artificial monolayers in their studies on $\mathrm{CO}_{2}$ exchange in a wind-wave tunnel, providing fundamental insights. However, Carlson (1993) pointed out that artificial monolayers do not mimic the complex nature of marine surface films, and therefore, studies on monolayers may have limited application in the global assessment of $\mathrm{CO}_{2}$ fluxes. Frew et al. (2004) reported that wave slopes and gas transfer velocities were correlated with chemical enrichment of CDOM, but the reported data set is too sparse for a global assessment. Calleja et al. (2009) suggest that consideration of organic carbon at the ocean surface (top few $\mathrm{cm})$ affects gas transfers velocity and may have important implications for a better understanding of the net $\mathrm{CO}_{2}$ flux across the global ocean. Clearly, future studies are required to assess the effects of surfactant enrichment in the SML on air-sea gas exchange rates. The maps on surfactant concentrations in the SML presented in Fig. 8 are an incremental contribution to the assessment of global gas fluxes between the ocean and atmosphere.

\section{Conclusions}

Our study suggests that the ocean surface microlayer may be enriched with surfactants, relative to the underlying waters, to a much larger extent than previously recognized. The SML surfactant enrichment generally appears to be greater in low-productivity regions of the ocean (i.e., under oligotrophic conditions) than in productive coastal waters. The differences in enrichment may originate from the nature of organic material, especially in regards to resistance to degradation by UV radiation and enhanced microbial activities in the SML.

Furthermore the enrichment of surfactants persists at moderate wind speeds, up to nearly $10 \mathrm{~m} \mathrm{~s}^{-1}$. This supports the known effect of bubble-mediating upward transport of surfactants within the water column, which facilitates rapid reformation of the SML in the presence of breaking waves. Our study shows that the SML exists under typical oceanic conditions, that is, under typical wind regimes and oligotrophic conditions. We therefore suggest that the potential impact of the SML on air-sea gas exchange and biogeochemical cycling may be of global significance.

Acknowledgements. The authors would like to thank Fisheries and Oceans Canada, the Office of Naval Research (ONR, Contract N 000140710754), and ArcticNet for financial support. O. Wurl thanks the Deutsche Forschungsgemeinschaft (DFG) for a postdoctoral scholarship (WU 585/2-1). We thank Jay Cullen (University of Victoria) for providing us the mercury drop electrode. The officers and crew of CCGS JP Tully, RV Kilo Moana, and NGCC Amundsen are acknowledged for their invaluable support during sample collection.

Edited by: G. Herndl

\section{References}

Allan, G. G., Lewin, J., and Johnson, P. G.: Marine polymers. IV. Diatom polysaccharides, Bot. Mar., 25, 102-108, 1972.

Antoine, D., Andre, J.-M., and Morel, A.: Oceanic primary production: 2. Estimation at global scale from satellite (CZone Color Scanner) chlorophyll, Global Biogeochem. Cy., 10, 5769, doi:10.1029/95GB02832, 1996.

Archer, C. L. and Jacobson, M. Z.: Evaluation of global wind power, J. Geophys. Res., 110, D12110, doi:10.1029/2004JD005462, 2005.

Asher, W.: The sea-surface microlayer and its effect on global airsea transfer, in: The sea surface and global change, edited by: Liss, P. S. and Duce, R. A., Cambridge University Press, 251285, 1997.

Asher, W. E., Karle, L. M., Higgins, B. J., Farley, P. J., Monahan, E. C., and Leifer, I. S. : The influence of bubble plumes on air-seawater gas transfer velocities, J. Geophys. Res., 101(C5), 12027-12041, 1996.

Azam, F. and Malfatti, F.: Microbial structuring of marine ecosystems, Nature Rev., 5, 782-791, 2007.

Baastrup-Spohr, L. and Staehr, P. A.: Surface microlayers on temperate lowland lakes, Hydrobiologia, 625, 43-59, 2009.

Behrenfeld, M. J. and Falkowski, P. G.: A consumer's guide to phytoplankton primary productivity models, Limnol. Oceanogr., 42(7), 1479-1491, 1997.

Borch, N. H. and Kirchman, D. L.: Concentration and composition of dissolved combined neutral sugars (polysaccharides) in seawater determined by HPLC-PAD, Mar. Chem., 57, 85-97, 1997.

Broecker, H.-C., Petermann, J., and Siems, W.: The influence of wind on $\mathrm{CO}_{2}$-exchange in a wind-wave tunnel, including the effects of monolayers, J. Mar. Res., 36, 595-610, 1978.

Calace, N., Catrambone, T., Petronio, B. M., and Pietroletti, M.: Fulvic acids in microlayer waters of the Gerlache Inlet Sea (Antarctica): Their distribution in dissolved and particulate phase, Water Res., 41, 152-158, 2007.

Calleja, M. L1., Duarte, C. M., Prairie, Y. T., Agustí, S., and Herndl, G. J.: Evidence for surface organic matter modulation of air-sea $\mathrm{CO}_{2}$ gas exchange, Biogeosciences, 6, 1105-1114, doi:10.5194/bg-6-1105-2009, 2009.

Carlson, D. J.: A field evaluation of plate and screen microlayer sampling techniques, Mar. Chem., 11, 189-208, 1982.

Carlson, D. J.: Dissolved organic materials in surface microlayers: Temporal and spatial variability and relation to sea state, Limnol. Oceanogr., 28(3), 415-431, 1983.

Carlson, D. J.: The early diagenesis of organic matter: reaction at the air-sea interface, in: Organic geochemistry: Principles and Applications, edited by: Engel, M. H. and Macko, S. A., Plenum Press, New York, 255-267, 1993. 
Ćosović, B. and Vojvodić, V.: Voltammetric analysis of surface active substances in natural seawater, Electroanalysis, 10, 429-434, 1998.

Cunliffe, M., Salter, M., Mann, P. J., Whiteley, A. S., UpstillGoddard, R. C., and Murrell, J. C.: Dissolved organic carbon and bacterial populations in the gelatinous surface microlayer of a Norwegian fjord mesocosm, FEMS Microbiol. Lett., 299, 248254, 2009.

Dragćević, D. and Pravdić, V.: Properties of the seawater-air interface: rates of surface fim formation under steady state conditions, Limnol. Oceanogr., 26, 492-499, 1981.

Frew, N. M., Nelson, R. K. , McGillis, W. R., Edson, J. B., Bock, E. J., and Hara, T.: Spatial variations in surface microlayer surfactants and their role in modulating air-sea exchange, in: Gas transfer at water surfaces, edited by: Donelan, M. A., Drennan, W. M., Saltzman, E. S., and Wannickhof, R., Geophys. Monogr. Ser., AGU, 127, 153-159, 2002.

Frew, N. M., Bock, E. J., Schimpf, U., Hara, T., Haußecker, H., Edson, J. B., McGillis, W. R., Nelson, R. K., McKenna, S. P., and Jähne, B.: Air-sea gas transfer: Its dependence on wind stress, small-scale roughness, and surface films, J. Geophys. Res., 109, C08S17, doi:10.1029/2003JC002131, 2004.

GESAMP (IMO/FAO/Unesco-IOC/WMO/WHO/IAEA/UN/UNEP Joint Group of Experts on the Scientific Aspects of Marine Environmental Protection): The Sea-Surface Microlayer and its Role in Global Change, Rep. Stud. GESAMP, p. 9, 1995.

Goldmann, J. C., Dennett, M. R., and Frew, N. M.: Surfactant effects on air-sea gas exchange under turbulent conditions, DeepSea Res., 35, 1953-1970, 1988.

Harrison, P. J., Boyd, P. W., Varela, D. E., Takeda, S., Shiomoto, A., and Odate, T.: Comparison of factors controlling phytoplankton productivity in the NE and NW subarctic Pacific gyres, Prog. Oceanogr., 43, 205-234, 1999.

Harvey, G. W. and Burzell, L. A.: A simple microlayer method for small samples, Limnol. Oceanogr., 17(1), 156-157, 1972.

Hillbrecht-Ilkowska, A. and Kostrzewska-Szlakowska, I.: Surface microlayer in lakes of different trophic states: Nutrients concentration and accumulation, Pol. J. Ecol., 52(4), 461-478, 2004.

Holm-Hansen, O., Naganobu, M., Kawaguchi, S., Kameda, T., Krasovski, I., Tchernyshkov, P., Priddle, J., Korb, R., Brandon, M., Demer, D., Hewitt, R. P., Kahru, M., and Hewes, C. D.: Factors influencing the distribution, biomass, and productivity of phytoplankton in the Scotia Sea and adjoining waters, Deep-Sea Res. Pt. II, 51, 1333-1350, 2004.

Hunter, K. A.: Processes affecting particulate trace metals in the sea surface microlayer, Mar. Chem., 9, 49-70, 1980.

Hwang, P. A. and Sletten, M. A.: Energy dissipation of windgenerated waves and white-cap coverage. J. Geophys. Res.Oceans, 113, C02012, doi:10.1029/2007/JC004277, 2008.

Jeffrey, S. W. and Humphrey, G. F.: New spectrophotometric equations for determining chlorophylls a, b, c1, c2 in higher plants, algae and natural phytoplankton, Biochem. Physiol. Pfl., 167, 191-198, 1975.

Jiao, N., Herndl, G. J., Hansell, D. A., Benner, R., Kattner, G., Wilhelm, S. W., Kirchman, D. L., Weinbauer, M. G., Luo, T., Chen, F., and Azam, F.: Microbial production of recalcitrant dissolved organic matter: long-term carbon storage in the global ocean, Nat. Rev. Microbiol., 8, 593-599, 2010.

Johnson, B. D. and Cooke, R. C.: Organic particle and aggregate formation resulting from the dissolution of bubbles in seawater, Limnol. Oceanogr., 25, 653-681, 1980.

Kalnay, E., Kanamitsu, M., Kistler, R., Collins, W., Deaven, D., Gandin, L., Iredell, M., Saha, S., White, G., Woollen, J., Zhu, Y., Leetmaa, A., Reynolds, R., Chelliah, M., Ebisuzaki, W., Higgins, W., Janowiak, J., Mo, K. C., Ropelewski, C., Wang, J., Jenne, R., and Joseph, D.: The NCEP/NCAR 40-year reanalysis project, B. Am. Meteorol. Soc., 77, 437-470, 1996.

Karl, D. M., Hebel, D. V., Björkman, K., and Letelier, R. M.: The role of dissolved organic matter release in the productivity of the oligotrophic North Pacific Ocean, Limnol. Oceanogr., 43, 1270 1283, 1998.

Kostrzewska-Szlakowska, I.: Surface microlayer in lakes of different trophic status: Dissolved organic matter and microbial community, Pol. J. Ecol., 53, 341-351, 2005.

Kujawinski, E. B., Farrington, J. W., and Moffett, J. W.: Evidence for grazing-mediated production of dissolved surface-active material by marine protists, Mar. Chem., 77, 133-142, 2002.

Kuznetsova, M., Lee, C., Aller, J., and Frew, N.: Enrichment of amino acids in the sea surface microlayer at coastal and open ocean sites in the North Atlantic Ocean, Limnol. Oceanogr., 49(5), 1605-1619, 2004.

Lavoie, D., MacDonald, R. W., and Denman, K. L.: Primary productivity and export fluxes on the Canadian shelf of the Beaufort Sea: A modelling study, J. Marine Syst., 75, 17-32, 2009.

Liss, P. S.: Chemistry of the sea surface microlayer, in: Chemical oceanography Vol. 2, edited by: Riley, J. P. and Skirrow, G., Academic Press, London, 193-244, 1975.

Liss, P. S. and Duce, R. A.: 1997: The Sea Surface and Global Change, Cambridge University Press, 1997.

Lui, K. and Dickhut, R. M.: Effects of wind speed and particulate matter source on surface microlayer characteristics and enrichment of organic matter in southern Chesapeake Bay, J. Geophys. Res., 103(D9), 10571-10577, 1998.

Motulsky, H. J.: Prism 4 Statistics Guide - Statistical analyses for laboratory and clinical researchers, GraphPad Software Inc., San Diego CA, www.graphpad.com, 2003.

Myklestad, S.: Production of carbohydrates by marine planktonic diatoms. I. Comparision of nine different species in culture, J. Exp. Mar. Biol. Ecol., 15, 261-274, 1974.

Myklestad, S. M., Skånøy, E., and Hestman, S.: A sensitive and rapid method for analysis of dissolved mono- and polysaccharides in seawater, Mar. Chem., 56, 279-286, 1997.

Obernosterer, I., Catala, P., Lami, R., Caparros, J., Ras, J., Bricaud, A., Dupuy, C., van Wambeke, F., and Lebaron, P.: Biochemical characteristics and bacterial community structure of the sea surface microlayer in the South Pacific Ocean, Biogeosciences, 5, 693-705, doi:10.5194/bg-5-693-2008, 2008.

Opsahl, S. and Benner, R.: Photochemical reactivity of dissolved lignin in river and ocean waters, Limnol. Oceanogr., 43(6), 1297-1304, 1998.

Pierson Jr., W. J. and Moscowitz, L.: A proposed spectral form for fully developed wind seas based on the similarity theory of S. A. Kitaigorodskii, J. Geophys. Res., 69, 5181-5190, 1964.

Plavšić, M. and Ćosović, B.: Adsorption properties of different polysaccharides on mercury in sodium chloride solutions, Electroanalysis, 12, 895-900, 2000.

Preisendorfer, R. W.: Secchi disk science: Visual optics of natural waters, Limnol. Oceanogr., 31(5), 909-926, 1986. 
Reinthaler, T., Sintes, E., and Herndl, G. J.: Dissolved organic matter and bacterial production and respiration in the sea-surface microlayer of the open Atlantic and the western Mediterranean Sea, Limnol. Oceanogr., 53(1), 122-136, 2008.

Sakugawa, H. and Handa, N.: Isolation and chemical characterization of dissolved and particulate polysaccharides in Mikawa Bay, Geochim. Cosmochim. Ac., 49, 1185-1193, 1985.

Sander, S. and Henze, G.: AC-voltammetric determination of the total concentration of nonionic and anionic surfactants in aqueous systems, Electroanalysis, 9, 243-246, 1997.

Sieburth, J. McN., Willis, P.-J., Johnson, K. M., Burney, C. M., Lavoie, D. M., Hinga, K. R., Caron, D. A., French III, F. W., Johnson, P. W., and Davis, P. G.: Dissolved organic matter and heterotrophic microneuston in the surface microlayers of the North Atlantic, Science, 194, 1415-1418, 1976.

Siegel, D. A., Doney, S. C., and Yoder, J. A.: The North Atlantic spring phytoplankton bloom and Sverdrup's critical depth hypothesis, Science, 296, 730-733, 2002.

Shipe, R. F. and Brzenzinski, M. A.: Siliceous plankton dominate primary and new productivity during the onset of El Nino conditions in the Santa Barbara Basin, California, J. Marine Syst., 42, 127-143, 2003.

Sholkovitz, E. R., Boyle, E. Q., and Price, N. B.: The removal of dissolved humic acids and iron during estuarine mixing, Earth Planet. Sc. Lett. 40, 130-136, 1978.

Södergren, A.: Origin and composition of surface slicks in lakes of differing trophic status, Limnol. Oceanogr., 32(6), 1307-1316, 1987.

Stefan, R. L. and Szeri, A. J.: Surfactant scavenging and surface deposition by rising bubbles, J. Colloid Interf. Sci., 212, 1-13, 1999.

Strickland, J. D. H. and Parsons, T. R.: A practical handbook of seawater analysis, J. Fish. Res. Board Can., 167, 2nd edn., 311 pp., 1972.

Timothy, D. A. and Soon, M. Y. S.: Primary production and deepwater oxygen content of two British Columbian fjords, Mar. Chem., 73, 37-51, 2001.
Tsai, W.-T. and Lui, K.-K.: An assessment of the effects of seasurface surfactant on global atmosphere-ocean $\mathrm{CO}_{2}$ flux, J. Geophys. Res., 108, 3127-3143, 2003.

Welschmeyer, N. A., Strom, S., Goericke, R., DiTullio, G., Belvin, M., and Petersen, W.: Primary production in the subarctic Pacific Ocean: Project SUPER, Prog. Oceanogr., 32, 101-135, 1993.

Wheeler, J. R.: Formation and collapse of surface films, Limnol. Oceanogr., 20, 338-342, 1975.

Williams, P. M., Carlucci, A. F., Henrichs, S. M., Van Fleet, E. S., Horrigan, S. G., Reid, F. M. H., and Robertson, K. J.: Chemical and microbiological studies of sea-surface films in the Southern Gulf of California and off the West Coast of Baja California, Mar. Chem., 19, 17-98, 1986.

Wurl, O. and Holmes, M.: The gelatinous nature of the sea-surface microlayer, Mar. Chem., 110, 89-97, 2008.

Wurl, O., Miller, L., Röttgers, R. and Vagle, S.: The distribution and fate of surface-active substances in the sea-surface microlayer and water column, Mar. Chem., 115, 1-9, 2009.

Zhang, Z., Cai, W., Liu, L., Liu, C., and Chen, F.: Direct determination of thickness of sea surface microlayer using a $\mathrm{pH}$ microelectrode at original location, Sci. China Ser. B, 46, 339-351, 2003.

Zonnefeld, K. A. F., Susek, E., and Fischer, G.: Seasonal variability of the organic-walled dinoflagellate cyst production in the coastal upwelling region off Cape Blanc (Mauritania): A five year survey, J. Phycol., 46, 202-215, 2010.

Zhou, J., Mopper, K., and Passow, U.: The role of surface-active carbohydrates in the formation of transparent exopolymer particles by bubble adsorption of seawater, Limnol. Oceanogr., 43(8), 1860-1871, 1998.

Žutic, V., Ćosović, B., Marčenko, E., and Bihari, N.: Surfactant production by marine phytoplankton, Mar. Chem., 10, 505-520, 1981. 